\title{
Pengelolaan Zakat Produktif sebagai Instrumen Peningkatan Kesejahteraan Umat
}

\author{
Maltuf Fitri \\ UIN Walisongo Semarang \\ email: dodotirododotiro@gmail.com
}

\begin{abstract}
The purpose of zakat management formally is to (1) improve the effectiveness and efficiency of services in the management of zakat, and (2) to increase the benefits of zakat to realize the welfare of society and poverty reduction. In this context, the distribution of zakat funds in addition to the consumptive purpose, can also be justified for the purpose of growing productive economic activities for mustahiq. By law, the use of zakat for productive economic activity is also not prohibited, as long as the mandatory of fulfilling the basic needs of mustahiq has been done. The use of zakat funds for productive economic activities is a conception to liberate the socio-economic life of mustahiq with a view to changing from the recipient of zakat to the payer of zakat. The implementation scheme of this concept is to build or grow a business unit in mustahiq through grant funding for business capital. Within a certain production cycle, mustahiq will also receive technical assistance and guidance from the zakat management institution in order to plan the establishment of a successful business unit and that mustahiq has a permanent source of income.
\end{abstract}

Keywords: zakat; mustahiq; welfare people; productive economy activities

\begin{abstract}
Abstraks: Tujuan pengelolaan zakat secara formal adalah untuk meningkatkan efektifitas dan efisiensi pelayanan dalam pengelolaan zakat, dan meningkatkan manfaat zakat untuk mewujudkan kesejahteraan masyarakat dan penanggulangan kemiskinan. Dalam konteks ini, pendistribusian dana zakat selain untuk pemberian bantuan yang bersifat konsumtif, juga dapat dibenarkan untuk tujuan menumbuhkan kegiatan ekonomi produktif bagi penerima zakat (mustahik). Secara hukum, penggunaan zakat untuk kegiatan ekonomi produktif juga tidak dilarang, selama keberadaan para mustahik yang wajib dan harus dibantu sudah terpenuhi kebutuhan dasarnya. Penggunaan dana zakat untuk kegiatan ekonomi produktif adalah sebuah konsepsi untuk memandirikan penerima zakat secara sosial ekonomi dengan maksud untuk merubah dari penerima zakat menjadi pembayar zakat. Skema pelaksanaan dari konsep ini adalah membangun atau menumbuhkan unit usaha pada diri penerima zakat melalui pemberian dana hibah untuk modal usaha. Dalam satu siklus produksi tertentu, penerima zakat juga akan mendapat pendampingan dan bimbingan teknis dari lembaga pengelola zakat agar rencana membentuk unit usaha berhasil dan penerima zakat memiliki sumber pendapatan yang permanen.
\end{abstract}

Kata Kunci: zakat; mustahik; kesejahteraan umat; kegiatan ekonomi produktif

Economica: Jurnal Ekonomi Islam - Volume 8, Nomor 1 (2017) 
Maltuf

\section{Pendahuluan}

Zakat adalah kewajiban yang harus ditunaikan seorang muslim/muslimah sebagai pelaksanaan rukun ketiga dari lima rukun Islam di mana keberadaan zakat itu sendiri memiliki tujuan penanaman nilai keimanan. Jadi, zakat merupakan kewajiban agama yang harus dibayarkan oleh setiap muslim yang telah memenuhi ketentuan persyaratan dalam keadaan apa pun (Baehaqi 2005). Secara praksis, zakat adalah satu amalan ibadah yang berdimensi sosial-ekonomi. Karena dalam praktiknya, zakat digunakan sebagai sarana untuk membantu anggota masyarakat yang mengalami kesulitan sosial-ekonomi. Zakat menjadi wahana yang membentuk masyarakat untuk bekerjasama dan berperan sebagai penjamin perlindungan sosial bagi masyarakat.

Sebagai negara dengan jumlah penduduk muslim terbesar di dunia, isu zakat di Indonesia tidak hanya berhenti pada perspektif religius saja, namun juga bisa disikapi sebagai realitas sosial yaitu sebagai sumber daya nasional yang perlu dikelola dan diberdayakan secara amanah dan benar. Artinya, zakat adalah sumber daya ekonomi yang perlu dikelola dengan penuh tanggung jawab dan ditempatkan sebagai modal sosial-ekonomi untuk usaha-usaha memberdayakan umat (masyarakat). Menurut Forum Zakat Indonesia, potensi zakat di Indonesia mencapai Rp 300 triliun per tahun. Namun dari potensi yang besar itu, baru tercapai sekitar Rp 1,8 triliun per tahun (Nahaba 2012).

Di Indonesia, pengelolaan zakat secara formal diatur dalam Undang Undang Nomor 23 Tahun 2011 tentang Pengelolaan Zakat. Menurut UndangUndang tersebut terdapat 2 (dua) lembaga/badan yang berhak mengelola zakat, yaitu Badan Amil Zakat yang dikelola pemerintah dan Lembaga Amil Zakat yang dikelola masyarakat.

Tujuan pengelolaan zakat secara formal adalah untuk: (1) meningkatkan efektifitas dan efisiensi pelayanan dalam pengelolaan zakat, 
dan (2) meningkatkan manfaat zakat untuk mewujudkan kesejahteraan masyarakat dan penanggulangan kemiskinan. Rumusan tujuan di atas apabila ditelaah secara positif mengandung pengertian bahwa mengingat potensi zakat yang begitu besar maka perlu upaya secara kelembagaan agar pelayanan zakat berjalan efektif (tepat sasaran), serta dapat mendayagunakan untuk mendukung program-program pemberian jaminan perlindungan sosial dan peningkatan kesejahteraan umat. Adapun ruang lingkup pengelolaan zakat menurut Undang-Undang Nomor 23 Tahun 2011 meliputi kegiatan perencanaan, pelaksanaan, dan pengordinasian dalam pengumpulan, pendistribusian, dan pendayagunaan Zakat.

Dalam perkembangannya, implementasi Undang-Undang Nomor 23 Tahun 2011 menimbulkan polemik karena dianggap membatasi inisiatif dalam mengumpulkan zakat dan menyalurkan kembali kepada masyarakat. Penunjukkan dua lembaga yaitu Badan Amil Zakat Nasional (BAZNAS) dan Lembaga Amil Zakat (LAZ) dianggap dapat membatasi peran mandiri masyarakat dalam memberdayakan dana zakat.

Meskipun keberadaan Undang Undang Nomor 23 Tahun 2011 bertujuan memastikan keteraturan dan akuntabilitas dalam perencanaan pengumpulan, pendistribusian, dan pendayagunaan zakat; pelaksanaan pengumpulan, pendistribusian, dan pendayagunaan zakat; dan pelaporan dan pertanggungjawaban pelaksanaan pengelolaan zakat, namun hal tersebut ternyata tidak bisa serta merta dipersepsikan dengan pemahaman yang sama oleh masyarakat.

Terdapat dua alasan yang menyebabkan mengapa masyarakat belum bisa menerima konsep pengelolaan zakat menurut rumusan Undang Undang Nomor 23 Tahun 2011. Pertama, kuatnya sikap tradisional masyarakat yang lebih percaya menyalurkan zakat ke masjid terdekat atau lembaga penyalur yang ada di daerahnya. Cara ini dianggap lebih praktis. Kedua, masih adanya sikap sentimen/krisis kepercayaan terhadap kinerja sistem birokrasi dan 
Maltuf

good governance. Masyarakat masih khawatir jika zakat yang merupakan wujud ketaatan agama akan disalahgunakan untuk kepentingan politis.

Apa yang dipersepsikan oleh masyarakat adalah realitas sosial yang harus ditempatkan sebagai tantangan, karena dasar resistensinya bukan bersifat substantif, namun lebih kepada aspek teknis dan mekanisme pelaksanaan. Jadi, konsep pengelolaan zakat berbasis pemberdayaan dan peningkatan kesejahteraan umat sepanjang hal tersebut tidak bertentangan dengan maksud dan tujuan dari zakat, maka hal tersebut sangat relevan untuk dilembagakan dan diimplementasikan.

Tulisan ini bertujuan memaparkan konsepsi pengelolaan zakat sebagai potensi sosial ekonomi yang dapat didayagunakan untuk memberdayakan dan meningkatkan kesejahteraan umat. Dasar pemikirannya adalah ketika potensi zakat dihimpun dan dikelola oleh lembaga pengelola zakat yang terorganisir dengan cakupan layanan lebih luas serta ditangani oleh personal yang amanah dan profesional, maka zakat dapat dihimpun lebih maksimal. Jika hal tersebut dapat terwujud, maka fungsi zakat akan dapat diperluas tidak sekedar memberikan bantuan jaminan perlindungan sosial kepada mereka yang berhak menerima zakat, tetapi juga dapat digunakan untuk upaya peningkatan status dan kondisi sosial ekonominya.

\section{Pengertian Zakat}

Zakat (zakāt) secara etimologi, berasal dari kata dasar زكى - زيزكو yang زكت الثجرة berarti "berkah, tumbuh, bersih dan baik." Misalnya, dalam kalimat yang artinya "pohon itu tumbuh dan berkembang", dan زكا رجل yang artinya "seorang itu baik". Harta yang dikeluarkan untuk zakat dinamakan zakat karena harta tersebut mensucikan diri orang yang berzakat (muzakki) dari kotoran kikir dan dosa, menyuburkan harta yang tersisa, memperbanyak pahala bagi yang mengeluarkan, serta menyuburkan dan mensucikan masyarakat secara keseluruhan. Demikian itu, karena zakat adalah manifestasi dari sikap gotong royong antara orang kaya dan fakir miskin, 
sekaligus merupakan bentuk perlindungan bagi masyarakat dari bencana sosial berupa kemiskinan dan kelemahan fisik maupun mental. Karena itu, Allah berfirman:

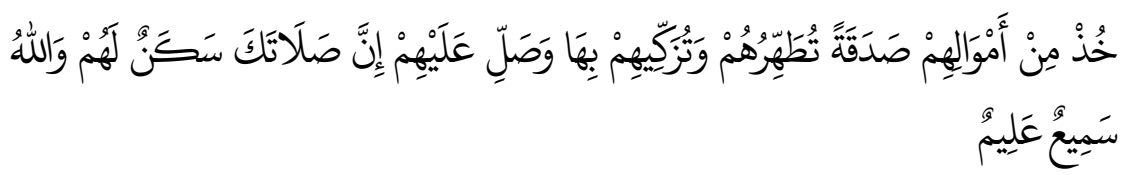

"Ambillah zakat dari sebagian harta mereka, dengan zakat itu kamu membersihkan dan mensucikan mereka, dan berdoalah untuk mereka. Sesungguhnya doamu itu (menjadi) ketenteraman jiwa bagi mereka. Dan Allah Maha Mendengar lagi Maha Mengetahui." (QS. al-Taubah [9]:103)

Sedangkan menurut istilah (terminologi), ada banyak definisi zakat yang dikemukakan. Abdul Mujieb, misalnya mendefinisikan zakat dengan mengeluarkan sejumlah harta tertentu untuk diberikan kepada orang-orang yang berhak menerimanya dengan syarat-syarat yang telah ditentukan oleh syara (Mujieb 1994). Menurut al-Syarbani, zakat adalah nama bagi sejumlah tertentu dari harta tertentu yang harus diberikan kepada pihak-pihak tertentu dengan syarat-syarat tertentu pula (al-Syarbani 1321). Pengertian yang sama juga dirumuskan al-Ghazzi bahwa zakat menurut syara ialah nama bagi suatu harta tertentu menurut cara-cara yang tertentu, kemudian diberikan kepada sekelompok orang yang tertentu pula (al-Ghazzi 2005). Sementara menurut Undang-Undang Nomor 23 Tahun 2011, zakat adalah harta yang wajib dikeluarkan oleh seorang muslim atau badan usaha untuk diberikan kepada yang berhak menerimanya sesuai dengan syariat Islam.

\section{Dasar Hukum Zakat}

Zakat merupakan rukun Islam ketiga sesudah syahadat dan shalat. Apabila dapat dilaksanakan dengan penuh kesadaran dan tanggung jawab oleh umat Islam, zakat dapat menjadi sumber penerimaan yang potensial guna menunjang suksesnya pembangunan nasional, terutama di bidang 
Maltuf

agama dan ekonomi, khususnya untuk membantu peningkatan pendapatan dan kesejahteraan masyarakat (Zuhdi 1994).

Adapun dalil-dalil yang menjadi dasar wajibnya melaksanakan zakat dalam Al-Qur'an di antaranya QS. al-Taubah [9]: 60, 103, al-Dzariyat [51]: 19, al-Baqarah [2]: 245, 261, 267, dan QS. Maryam [19]: 31. Di samping di dalam Al-Qur'an, terdapat beberapa hadis Nabi saw. tentang kewajiban zakat, antara lain sebagai berikut :

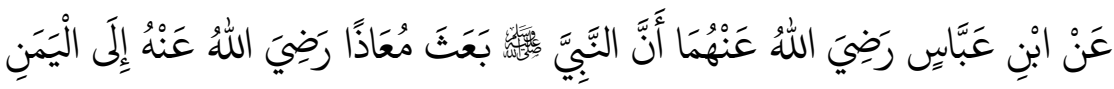

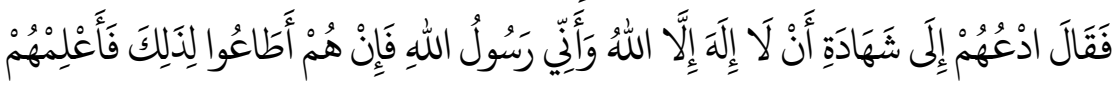

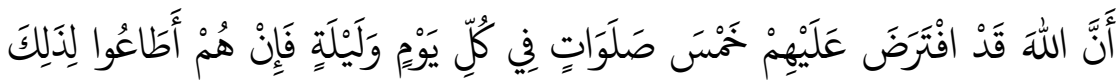

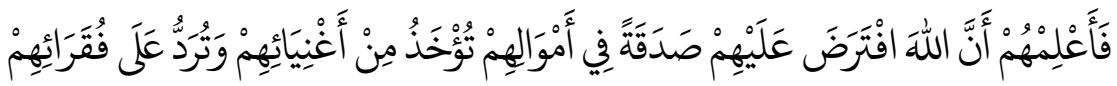

"Dari Ibnu Abbas ra, bahwa Nabi saw telah mengutus Mu'adz (bin Jabal) ra ke Yaman. Nabi saw bersabda: Serulah (ajaklah) mereka untuk mengakui bahwa tidak ada tuhan selain dan bahwa saya (Muhammad) adalah utusan Allah. Jika mereka menerima itu, maka beritahulah mereka bahwa Allah telah mewajibkan bagi mereka shalat lima waktu dalam sehari semalam. Jika mereka telah menerima itu, maka beritahulan mereka bahwa Allah telah mewajibkan zakat pada harta mereka; yang diambil dari orang-orang kaya di antara mereka dan diberikan kepada orang-orang fakir di antara mereka." (al-Bukhari 1987)

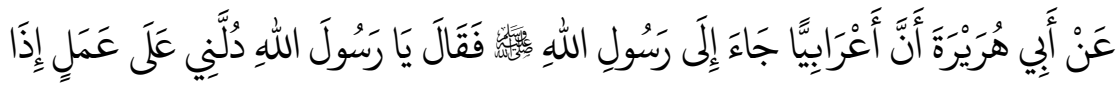

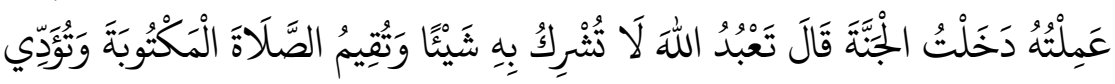

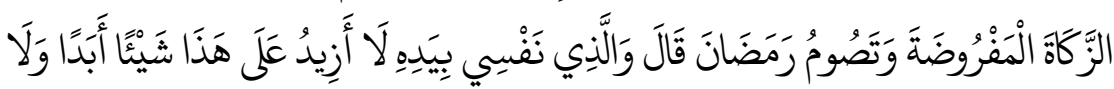

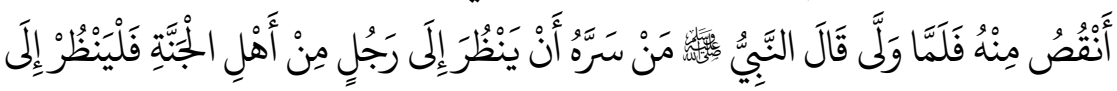


"Dari Abu Hurairah bahwa seorang Arab dusun datang kepada Rasulullah saw. dan bertanya: Wahai Rasulullah, tunjukkan kepadaku amal yang jika aku lakukan aku akan masuk surga! Beliau menjawab: Beribadah kepada Allah dan tidak menyekutukan-Nya, mendirikan shalat yang diwajibkan, menunaikan zakat yang diwajibkan, dan puasa Ramadhan. Dia berkata: Demi yang jiwaku berada dalam genggamanNya, aku sama sekali tidak akan menambah dan menguranginya. Ketika dia pergi, Nabi saw bersabda: Barangsiapa yang ingin melihat salah seorang penduduk surga maka lihatlah orang ini." (Muslim 1972)

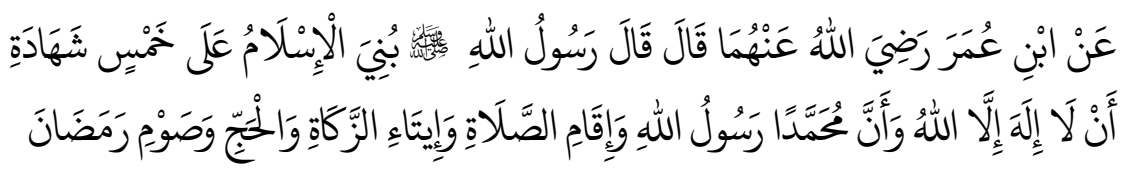

"Dari Ibnu Umar ra, bahwa Rasulullah saw. bersabda: Islam didirikan atas lima sendi: mengakui bahwa tidak ada tuhan (yang hak) selain Allah dan bahwa Muhammad adalah utusan Allah, mendirikan shalat, mengeluarkan zakat, mengerjakan haji dan berpuasa di bulan Ramadhan." (al-Bukhari 1987)

Ayat-ayat al-Qur'an dan hadis Rasulullah saw di atas menjelaskan tentang kewajiban mengeluarkan zakat, dan zakat tersebut merupakan salah satu dari rukun Islam yang harus dilaksanakan oleh seorang muslim.

\section{Tujuan dan Manfaat Zakat}

Islam juga menempatkan ibadah zakat sebagai konsepsi untuk menyejahterakan umat. Beberapa prinsip ekonomi Islam mendasari pengertian tersebut. Di antaranya, Islam memberi landasan nilai keyakinan bahwa (1) semua yang didapat dan dimiliki oleh manusia adalah karena seizin Allah, oleh karena itu barang siapa yang kurang beruntung memiliki hak atas kekayaan yang dimiliki oleh kaum yang beruntung, (2) kekayaan tidak boleh ditumpuk terus atau ditimbun, dan (3) kekayaan harus diputar.

Berangkat dari ketiga prinsip ekonomi Islam tersebut, maka tujuan ibadah zakat adalah:

Economica: Jurnal Ekonomi Islam - Volume 8, Nomor 1 (2017) http://journal.walisongo.ac.id/index.php/economica 
Maltuf

1. Untuk membersihkan/mensucikan jiwa muzakki dari sifat tercela seperti kikir dan egois/individualisme.

2. Untuk membersihkan harta dari kemungkinan bercampur dengan harta yang tidak halal.

3. Untuk mencegah berputarnya uang pada sekelompok kaum kaya.

4. Untuk meningkatkan kualitas dan kesejahteraan hidup manusia.

Sedangkan manfaat zakat antara lain (Sari 2006):

1. Sebagai perwujudan keimanan kepada Allah SWT.

2. Karena zakat merupakan hak mustahik di mana zakat berfungsi untuk menolong, membantu, dan membina mereka, terutama fakir miskin kearah kehidupan yang lebih baik;

3. Zakat adalah salah satu sumber pembangunan sarana dan prasarana;

4. Zakat untuk memasyarakatkan etika bisnis yang benar, sebab zakat itu bukanlah membersihkan harta yang kotor, tetapi mengeluarkan bagian dari hak orang lain dari harta yang kita usahakan dengan baik dan benar;

5. Indikator utama ketundukan seseorang terhadap ajaran Islam;

6. Membuka lapangan kerja yang luas;

7. Melipatgandakan penguasaan asset dan modal di tangan umat Islam;

\section{Penerima Zakat (Mustahik)}

Perintah membayar zakat diwajibkan bagi setiap umat Islam yang mampu melaksanakannya (ukuran ekonomi). Tetapi, bagi umat muslim yang tidak mampu atau dalam ukuran kualitatifnya menghadapi keterbatasan untuk mencukupi kebutuhan hidup sehari-hari bagi golongan ini tidak diwajibkan untuk membayar zakat. Dan sebaliknya, mereka justru harus diberikan zakat. Menurut ketentuan Islam, pihak yang berhak menerima zakat terdiri dari 8 golongan, yaitu: 
Pertama, al-fuqarä' atau orang fakir (orang melarat), yaitu orang yang amat sengsara hidupnya, tidak memiliki harta dan tidak mempunyai tenaga untuk menutupi kebutuhan dirinya dan keluarganya. Orang fakir adalah paling utama untuk mendapat zakat karena kondisi kebutuhan amat sangat karena tidak memiliki hal-hal untuk memenuhi kebutuhan hidupnya.

Kedua, al-masākin atau orang miskin. Orang miskin berbeda dengan orang fakir. Ia tidak melarat, ia mempunyai penghasilan dan pekerjaan tetap tapi dalam keadaan kekurangan, tidak mencukupi untuk menutupi kebutuhan dirinya dan keluarganya. Misalnya, seseorang bekerja sebagai tukang sampah, tetapi penghasilannya hanya memenuhi setengah dari kebutuhannya. Orang seperti ini berhak mendapatkan zakat untuk memenuhi kebutuhannya.

Ketiga, al-'àmilīn atau amil zakat (panitia zakat). Amil adalah orang yang dipilih oleh pihak berwenang untuk mengumpulkan dan membagikan zakat kepada golongan yang berhak menerimanya. Amil zakat adalah mereka ahli dalam mengelola zakat. Mereka harus memiliki syarat tertentu yaitu muslim, akil dan balig, merdeka, adil (bijaksana), medengar, melihat, laki-laki dan mengerti tentang hukum agama.

Keempat, al-muallafah yaitu orang yang baru masuk Islam dan belum mantap imannya. seorang muallaf berhak mendapatkan zakat agar mereka yang baru masuk Islam dalam keadaan harta sedikit dan keimanan lemah harus didekati dengan bantuan zakat.

Kelima, al-riqāb atau hamba sahaya, yaitu yang ingin memerdekan dirinya dari majikannya dengan tebusan uang. Zakat dalam hal ini berfungsi untuk membebaskan seorang muslim yang ditawan oleh orang orang kafir. Ataupun zakat digunakan juga untuk membebaskan seorang budak muslim dari majikannya agar merdeka.

Keenam, al-ghārim atau orang yang terlilit utang. Mereka yang memiliki utang meskipun mampu dapat dibantu dengan zakat. 
Maltuf

Ketujuh, fi sabīlillāh yaitu orang yang berjuang di jalan Allah (sabīlillāh) tanpa imbalan karena merelakan dirinya bekerja dan berjuang untuk kepentingan Islam.

Kedelapan, ibn sabīl, yaitu musafir yang sedang dalam perjalanan (ibn sabil) yang bukan bertujuan maksiat di negeri rantauan, lalu mengalami kesulitan dan kesengsaraan dalam perjalanannya (Shonhaji 2014).

\section{Konsep Pengelolaan Zakat untuk Peningkatan Kesejahteraan Umat \\ Zakat dan Kesejahteraan Sosial (Umat)}

Secara formal ketentuan tentang konsep kesejahteraan sosial diatur dalam UU No.11 Tahun 1999 tentang Kesejahteraan Sosial. UU ini merupakan pengganti atau revisi UU No. 6 Tahun 1974 tentang Ketentuanketentuan Pokok Kesejahteraan Sosial. Menurut UU No.11 Tahun 1999, kesejahteraan sosial adalah kondisi terpenuhinya kebutuhan material, spiritual, dan sosial warga negara agar dapat hidup layak dan mampu mengembangkan diri, sehingga dapat melaksanakan fungsi sosialnya.

Menurut Edi Suharto (Suharto 2006), kesejahteraan sosial akan tercipta jika terpenuhi tiga hal yaitu: Pertama, kondisi statis atau keadaan sejahtera yang ditandai dengan terpenuhinya kebutuhan-kebutuhan jasmaniah, rohaniah, dan sosial. Kedua, kondisi dinamis, yakni tersedianya usaha atau kegiatan yang terorganisir untuk mencapai kondisi statis tersebut. Ketiga, adanya institusi atau bidang kegiatan yang melibatkan lembaga kesejahteraan sosial.

Konsep kesejahteraan sosial menurut perspektif ekonomi Islam didasarkan atas keseluruhan ajaran Islam dalam memandang segala aspek kehidupan termasuk tentang kesejahteraan sosial. Berdasarkan pandangan Islam rumusan kesejahteraan sosial mencakup: 
Pengelolaan Zakat Produktif sebagai Instrumen...

1. Kesejahteraan holistik dan seimbang. Artinya kesejahteraan ini mencakup dimensi materiil maupun spiritual serta mencakup individu maupun sosial.

2. Kesejahteraan di dunia maupun di akhirat, sebab manusia tidak hanya hidup di dunia saja tetapi juga di akhirat. Istilah umum yang banyak digunakan untuk menggambarkan suatu keadaan hidup yang sejahtera secara materiil-spiritual pada kehidupan dunia maupun akhirat dalam bingkai ajaran Islam adalah falāh. Dalam pengertian sederhana falāh adalah kemuliaan dan kemenangan hidup (Anto 2003).

Dengan demikian kesejahteraan sosial dalam perpsektif Islam adalah tentang bagaimana hubungan ajaran agama dengan kehidupan umat. Atas dasar perspektif tersebut, maka istilah kesejahteraan umat, menyangkut gambaran atmosfir keagamaan yakni dari sisi hubungan ajaran agama dengan kehidupan umat dalam hal ini hubungan ajaran Islam dengan umat Islam.

Kesejahteraan umat dapat dilihat dari sisi manusia sebagai komunitas keagamaan yang memiliki kebutuhan-kebutuhan sosial ekonomi dan politik dalam arti sebagai manausia dalam melakukan interaksi dengan lingkungan sosialnya pada satu sisi dan penciptaan hubungan dengan Tuhan sebagai konsekuensi sebagai makhluk yang beragama.

Berdasarkan uraian di atas, dapat ditarik pemahaman bahwa kesejahteraan sosial dikaitkan dengan kesejahteraan umat terdapat unsurunsur yang harus dipenuhi di antaranya kondisi kehidupan yang mendukung terwujudnya pemenuhan sosial, ekonomi, dan religious umat Islam, kondisi tersebut didukung partisipasi umat untuk memenuhi kebutuhan mereka, adanya institusi keagamaan yang lebih dinamis untuk mendorong pencapaian kesejahteraan sosial (Zulaikha 2012).

Economica: Jurnal Ekonomi Islam - Volume 8, Nomor 1 (2017) http://journal.walisongo.ac.id/index.php/economica 
Maltuf

\section{Zakat sebagai Potensi Kesejahteraan Umat}

Di dalam sistem ekonomi Islam terdapat konsepsi tentang azas-azas kebersamaan dan keadilan sosial-ekonomi. Perintah untuk membayar zakat, sedekah, infak dan wakaf merupakan bukti tegas bahwa Islam tidak menghendaki adanya kesenjangan ekonomi antara kelompok berada dan kelompok miskin. Melalui zakat juga mencegah terjadinya akumulasi harta pada beberapa orang saja.

Membayar zakat merupakan wujud pelaksanaan ibadah guna menghindarkan diri dari kekufuran sekaligus untuk mengeliminir munculnya sifat iri dan dengki ketika si miskin melihat kelompok masyarakat kaya. Sejumlah penelitian juga telah menjelaskan adanya korelasi zakat dan keadilan sosial yaitu mendeskripsikan Islam mensyariatkan zakat dengan tujuan meratakan jaminan sosial (keadilan sosial). Karena zakat adalah dana yang dipungut dari si kaya untuk diberikan kepada si miskin. Jadi tujuan zakat sangat jelas untuk mendistribusikan harta di masyarakat dengan cara sedemikan rupa sehingga tidak seorang pun umat Islam yang tinggal dalam keadaan miskin dan menderita (Baehaqi 2005).

Oleh karenanya apabila ketaatan membayar zakat ini berlangsung komperehensif maka zakat akan dapat menjadi potensi ekonomi sebagai sumber dana pembangunan bagi terbangunnya sarana dan prasarana sosial ekonomi yang dibutuhkan umat. Bahkan sangat mungkin zakat dapat didayagunakan untuk mendukung program-program bagi peningkatan kualitas sumber daya manusia. Ketika pemerataan pendapatan ini memberikan dampak simultan bagi pertumbuhan ekonomi maka zakat merupakan konsepsi economic growth with equity.

\section{Zakat dalam Usaha Produktif}

Berikhtiar atau berusaha merupakan upaya manusia untuk meningkatkan kesejahteraan. Karena dengan bekerja akan dihasilkan harta 
benda atau sumber pendapatan guna memenuhi kebutuhan. Bisa dikatakan hampir semua mustahik mustahil dapat memiliki kegiatan usaha produktif sebagai sumber pendapatan karena mereka memiliki sejumlah keterbatasan dalam memenuhi kebutuhan hidup sehari-hari. Padahal salah satu syarat untuk menumbuhkan keinginan bekerja atau berusaha dibutuhkan adanya modal usaha (dana).

Dalam Islam keterbatasan yang dialami mustahik sangat dapat diatasi dengan keberadaan zakat karena zakat merupakan potensi sosial ekonomi yang dapat membentuk masyarakat untuk bekerja sama bertindak sebagai lembaga penjamin dan penyedia dana cadangan bagi masyarakat muslim (Sariningrum 2011). Dalam pengertian yang lebih luas zakat juga memiliki keterkaitan erat dengan kegiatan produksi. Jika diasumsikan para muzakki adalah golongan yang umumnya bekerja sebagai produsen, maka manfaat zakat oleh produsen akan dirasakan dari adanya peningkatan konsumsi yang terus terjaga, karena zakat yang dibayarkan akan dibelanjakan oleh mustahik untuk mengkonsumsi barang dan jasa dari produsen. Jadi semakin tinggi jumlah zakat, maka semakin tinggi pula konsumsi mustahik sehingga dapat mendorong peningkatan skala ekonomi.

Oleh karena itu ketika untuk menumbuhkan kegiatan usaha produktif pada diri para mustahik maka hal tersebut dapat dipenuhi dengan keberadaan zakat. Zakat tidak hanya dimanfaatkan untuk kebutuhan bersifat konsumtif, tetapi juga diberdayakan secara produktif. Karena dengan pola pemanfaatan seperti ini akan membantu para mustahik tidak hanya dalam jangka pendek tetapi untuk kebutuhan dalam jangka panjang.

\section{Pendayagunaan Zakat untuk Ekonomi Produktif}

Menurut Shinta Dwi Wulansari (Wulansari, Analisis Peranan Dana Zakat Produktif Terhadap Perkembangan Usaha Mikro Mustahik (Penerimaan Zakat) (Studi Kasus Rumah Zakat Kota Semarang) 2013), pendayagunaan zakat pada prinsipnya berkaitan dengan bagaimana cara atau teknis 
Maltuf

pendistribusian agar tepat sasaran dan berdayaguna bagi penerima. Dalam Undang-Undang No. 23 tahun 2011 tentang Pengelolaan Zakat, dijelaskan mengenai konsepsi pendayagunaan zakat yaitu :

1. Zakat dapat didayagunakan untuk usaha produktif dalam rangka penanganan fakir miskin dan peningkatan kualitas umat, sebagaimana konsep pendayagunaan zakat produktif yang dilakukann di Rumah Zakat Semarang.

2. Pendayagunaan zakat untuk usaha produktif sebagaimana dimaksud pada ayat (1) dilakukan apabila kebutuhan dasar mustahik telah terpenuhi.

Lebih lanjut tentang pendayagunaan dana zakat, terdapat beberapa syarat yang harus dipenuhi oleh pihak penyalur zakat atau lembaga pengelola zakat. Hal tersebut diatur dalam keputusan Menteri Agama RI No. 373 tahun 2003 tentang pengelolaan dana zakat. Adapun jenis-jenis kegiatan pendayagunaan dana zakat :

a. Berbasis sosial

Penyaluran zakat jenis ini dilakukan dalam bentuk pemberian dana langsung berupa santunan sebagai bentuk pemenuhan kebutuhan pokok mustahik. Ini disebut juga program karitas (santunan) atau hibah konsumtif. Program ini merupakan bentuk yang paling sederhana dari penyaluran dana zakat. Tujuan utama bentuk penyaluran ini adalan antara lain :

1. Untuk menjaga keperluan pokok mustahik,

2. Menjaga martabat dan kehormatan mustahik dari meminta-minta,

3. Menyediakan wahana bagi mustahik untuk meningkatkan pendapatan,

4. Mencegah terjadinya eksploitasi terhadap mustahik untuk kepentingan yang menyimpang. 
b. Berbasis pengembangan ekonomi

Penyaluran zakat jenis ini dilakukan dalam bentuk pemberian modal usaha kepada mustahik secara langsung maupun tidak langsung, yang pengelolaannya bisa melibatkan maupun tidak melibatkan mustahik. Penyaluran dana zakat ini diarahkan pada usaha ekonomi yang produktif, yang diharapkan hasilnya dapat mengangkat taraf kesejahteraan masyarakat.

Isu ekonomi dalam pengelolaan zakat memang sudah mulai menjadi pemikiran yang logis oleh beberapa pihak. Dalam aspek kekinian pengelolaan zakat menurut dimensi ekonomi dikenal dengan istilah zakat konsumtif dan zakat produktif (Nasution 2008). Beberapa lembaga pengelolaan zakat mulai menerapkan metode ini. Secara umum kedua kategori zakat ini dibedakan berdasarkan bentuk pemberian zakat dan penggunaan dana zakat itu oleh mustahik. Masingmasing dari kebutuhan konsumtif dan produktif tersebut kemudian dibagi dua, yaitu konsumtif tradisional dan konsumtif kreatif, sedangkan yang berbentuk produktif dibagi menjadi produktif konvensional dan produktif kreatif. Adapun penjelasan lebih rinci dari keempat bentuk penyaluran zakat tersebut adalah :

1. Konsumtif Tradisional.

Maksud pendistribusian zakat secara konsumtif tradisional adalah bahwa zakat dibagikan kepada mustahik dengan secara langsung untuk kebutuhan konsumsi sehari-hari, seperti pembagian zakat fitrah berupa beras dan uang kepada fakir miskin setiap Idul Fitri atau pembagian zakat mal secara langsung oleh para muzakki kepada mustahik yang sangat membutuhkan karena ketiadaan pangan atau karena mengalami musibah. Pola ini merupakan program jangka pendek dalam rangka mengatasi permasalahan umat. 
Maltuf

2. Konsumtif Kreatif.

Pendistribusian zakat secara konsumtif kreatif adalah zakat yang diwujudkan dalam bentuk barang konsumtif dan digunakan untuk membantu orang miskin dalam mengatasi permasalahan sosial dan ekonomi yang dihadapinya. Bantuan tersebut antara lain berupa alat-alat sekolah dan beasiswa untuk para pelajar, bantuan sarana ibadah seperti sarung dan mukena, bantuan alat pertanian, seperti cangkul untuk petani, gerobak jualan untuk pedagang kecil.

3. Produktif Konvensional.

Pendistribusian zakat secara produktif konvensional adalah zakat yang diberikan dalam bentuk barang-barang produktif, di mana dengan menggunakan barang-barang tersebut, para muzakki dapat menciptakan suatu usaha, seperti pemberian bantuan ternak kambing, sapi perahan atau untuk membajak sawah, alat pertukangan, mesin jahit.

4. Produktif Kreatif.

Pendistribusian zakat secara produktif kreatif adalah zakat yang diwujudkan dalam bentuk pemberian modal bergulir, baik untuk pemodalan proyek sosial, seperti pembangunan sosial, pembangunan sekolah, sarana kesehatan atau tempat ibadah maupun sebagai modal usaha untuk membantu atau bagi pengembangan usaha para pedagang atau pengusaha kecil.

\section{Hukum Pengunaan Zakat untuk Ekonomi Produktif}

Keberadaan zakat sebagai salah satu amalan yang diwajibkan dalam Islam sejatinya bermakna untuk menyejahterakan umat. Zakat biasanya disalurkan untuk memenuhi kebutuhan kaum yang kurang mampu agar tetap bisa menjalankan kehidupan. Meski demikian, tidak sedikit praktik penggunaan zakat untuk kegiatan ekonomi produktif. Hal ini dimaksudkan 
agar kelompok mustahik (penerima zakat) dapat membuat usaha sendiri agar bisa mandiri secara finansial.

Atas fenomena ini Majelis Ulama Indonesia (MUI) telah mengeluarkan fatwa yang membolehkan penggunaan zakat untuk modal usaha. Hal itu tertuang dalam Fatwa Nomor 4 Tahun 2003 tentang Penggunaan Dana Zakat untuk istithmār (investasi). Dalam fatwa itu disebut beberapa syarat penggunaan zakat untuk modal usaha.

Pertama, zakat harus disalurkan pada usaha yang dibenarkan oleh syariah dan peraturan yang berlaku (al-țuruq al-mashru'ah). Kedua, diinvestasikan pada bidang-bidang usaha yang diyakini akan memberikan keuntungan atas dasar studi kelayakan. Ketiga, usaha tersebut harus dibina dan diawasi oleh pihak-pihak yang memiliki kompetensi. Keempat, usaha tersebut harus dijalankan oleh institusi/lembaga yang profesional dan dapat dipercaya (amanah). Kelima, modal usaha tersebut harus mendapat jaminan dari pemerintah dan pemerintah harus menggantinya apabila terjadi kerugian atau pailit. Keenam, tidak boleh ada kaum dhuafa (fakir miskin) yang kelaparan atau membutuhkan biaya yang tidak bisa ditunda pada saat harta zakat itu diinvestasikan. Ketujuh, penggunaan dana zakat untuk modal usaha yang di-ta'khir-kan karena diinvestasikan harus dibatasi waktunya.

\section{Konsepsi dan Prinsip Dasar Pengunaan Zakat untuk Ekonomi Produktif}

Prinsip dasar pemberian zakat adalah untuk memperbaiki taraf hidup umat yang masih berada di bawah garis kemiskinan. Transfer pendapatan ini bertujuan untuk meningkatkan daya beli orang miskin. Adapun sasaran zakat, yaitu antara lain memperbaiki taraf hidup, pendidikan dan beasiswa, mengatasi masalah ketenagakerjaan atau pengangguran, dan program pelayanan kesehatan.

Sasaran zakat untuk meningkatkan perbaikan taraf hidup tercermin dari meningkatnya konsumsi para penerima zakat. Karena orang yang

Economica: Jurnal Ekonomi Islam - Volume 8, Nomor 1 (2017) 
Maltuf

menerima zakat mempunyai kecenderungan mengkonsumsi marjinal (MPC) yang lebih tinggi secara signifikan akibat tambahan penerimaan. Dalam ekonomi Islam perekonomian secara makro terdiri atas dua karakteritik yang berbeda, yaitu muzakki dan mustahik.

$$
\begin{aligned}
& \mathrm{C} 1=\mathrm{a}+\mathrm{bY}(1-\mathrm{z}-\mathrm{f}) \\
& \mathrm{C} 2=\mathrm{zY}+\mathrm{fY} \\
& \text { Dimana: } \mathrm{C} 1=\text { Konsumsi muzakki (wajib zakat) } \\
& \mathrm{C} 2=\text { Konsumsi mustahik (penerima zakat) } \\
& \mathrm{C}=\mathrm{C} 1+\mathrm{C} 2 \\
& \mathrm{C}=\mathrm{a}+\mathrm{bY}(1-\mathrm{z}-\mathrm{f})+\mathrm{zY}+\mathrm{fY}
\end{aligned}
$$

Dimana $\mathrm{z}$ adalah besarnya zakat yang dibayarkan dan $\mathrm{f}$ adalah besarnya infak/sedekah.

Sementara konsepsi penggunaan zakat untuk kegiatan ekonomi produktif terumuskan dari sasaran zakat yang diarahkan untuk mengatasi ketenagakerjaan atau pengangguran. Pemberian dana zakat produktif kepada mustahik dapat diwujudkan dalam bentuk bantuan modal usaha. Zakat produktif yaitu zakat yang diberikan oleh lembaga amil kepada masyarakat yang membutuhkan bantuan modal, bantuan dana zakat produktif sebagai modal untuk menjalankan suatu kegiatan ekonomi yaitu untuk mengembangkan kondisi ekonomi dan potensi produktivitas mustahik. Singkatnya zakat produktif adalah harta zakat yang diberikan kepada mustahiq tidak dihabiskan atau dikosumsi tetapi dikembangkan dan digunakan untuk membantu usaha mereka, sehingga dengan usaha tersebut mustahiq dapat memenuhi kebutuhan hidup secara terus menerus.

Dengan adanya zakat baik itu zakat konsumtif dan produktif terjadi distribusi pendapatan dari muzakki dan middle income ke penerima zakat. Pada awalnya mustahik berada pada golongan paling bawah. Dengan adanya 
modal pihak mustahiq dapat meningkatkan pendapatannya melalui usaha produktif dari dana zakat yang diterima.

Dari alur distribusi pendapatan ini diharapkan susunan masyarakat akan berubah atau dengan tujuan menjadikan mustahik menjadi seorang muzakki. Hal ini dapat dilihat pada gambar 1.

Gambar 1. Perubahan Susunan Masyarakat Sebelum dan Sesudah Mendapatkan Bantuan Dana Zakat Produktif

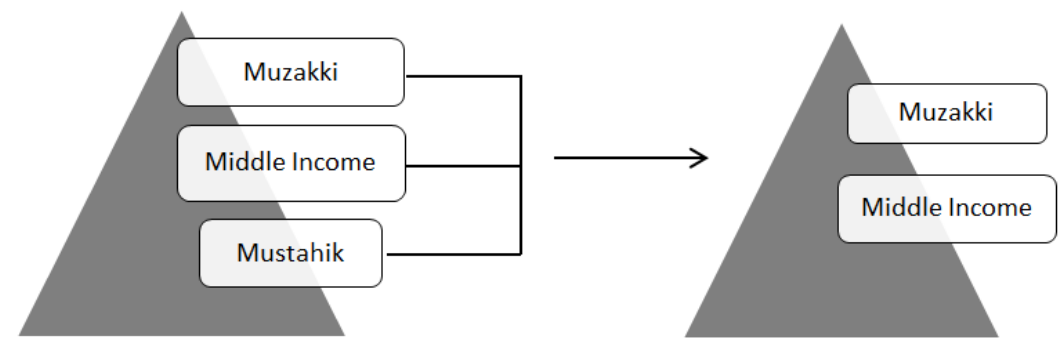

Sumber : (Asnaini 2008)

Prinsip-prinsip dasar yang harus dipenuhi dalam pengelolaan zakat untuk pendayagunaan kegiatan ekonomi produktif adalah:

1. Kebutuhan dasar para mustahik harus sudah terpenuhi terlebih dahulu.

Penggunaan dana zakat untuk pembiayaan kegiatan ekonomi produktif bisa dilakukan atau dibenarkan apabila di daerah pelayanan zakat sudah tidak ada mustahik yang mengalami kesulitan untuk memenuhi kebutuhan dasar.

2. Pendayagunaan dana zakat kegiatan ekonomi produktif diarahkan untuk membuat kegiatan unit usaha yang menghasilkan sumber penerimaan permanen bagi mustahik.

Dana zakat yang diberikan kepada mustahik tidak digunakan untuk kepentingan konsumtif tetapi untuk modal usaha/kerja. Dana zakat yang diterima diharapkan dapat mendukung beroperasinya kegiatan usaha yang direncanakan dan diharapkan pada periode waktu yang 
ditentukan akan menghasilkan penerimaan usaha yang secara perlahan dan kontinyu dapat menjadi sumber pendapatan yang bersifat permanen bagi mustahik. Apabila hal tersebut dapat terwujud maka mustahik akan naik kelas status sosial ekonominya menjadi muzakki.

3. Pendayagunaan dana zakat kegiatan ekonomi produktif merupakan program bersifat sukarela dan bermaksud mendidik kemandirian.

Keikutsertaan mustahik bersifat sukarela artinya tidak terdapat unsur paksaaan. Namun demikian untuk menumbuhkan kesadaran atau ketertarikan berusaha dapat dilakukan tahapan edukasi atau proses propaganda yang menjelaskan maksud dan tujuan tentang program pendayagunaan dana zakat untuk kegiatan ekonomi produktif yaitu pentingnya para mustahik agar memiliki kemandirian sosial ekonomi dengan cara berusaha (bekerja) atau memiliki kegiatan usaha agar mempunyai pendapatan sendiri untuk memenuhi kebutuhan hidup tanpa harus bergantung dengan pemberian orang lain.

4. Pemilihan bidang usaha harus melibatkan dan memperhatikan tingkat kemampuan mustahik.

Bisa dikatakan bahwa sebagian besar para mustahik bukan tidak mungkin merupakan personal yang belum pernah melakukan atau memiliki kegiatan usaha sama sekali. Oleh karena itu untuk menentukan jenis atau bidang usaha apa yang akan dijalankan hal mendasar yang harus dilakukan adalah memperhatikan tingkat kemampuan teknis mustahik terlebih dahulu antara lain dengan mengetahui ketrampilan teknis apa yang dimiliki atau dikuasai mustahik atau setidaknya mengetahui bidang usaha apa yang diinginkannya.

Tahapan ini esensinya merupakan cara melibatkan mustahik dalam menentukan pemilihan bidang usaha sehingga secara tidak sengaja hal tersebut merupakan upaya menumbuhkan mental berusaha 
pada diri para mustahik dan dana zakat adalah "hanya unsur yang pendukung" untuk mewujudkan cita-cita memiliki usaha yang diharapkan.

Hal lain yang harus digarisbawahi apabila para mustahik tidak dilibatkan maka si perima program ini akan merasa hanya dimobilisasi dan tidak merasa memiliki kegiatan usaha ini. Kondisi seperti ini dikhawatirkan akan menjadikan program pendayagunaan zakat untuk kegiatan ekonomi produktif tidak akan berjalan efektif sehingga hanya akan menghabiskan sumber daya ekonomi secara percuma. Sementara kapasitas dana zakat bersifat terbatas.

5. Pendayagunaan dana zakat untuk kegiatan ekonomi produktif harus dilengkapi dengan program pendampingan teknis dan manajemen.

Sebagai pelaku usaha baru yang sebelumnya bisa jadi tidak pernah melakukan kegiatan ekonomi produktif sama sekali tentunya masih memerlukan bantuan teknis. Oleh karena itu agar tidak mengeliminir kesalahan para mustahik penerima program ini harus mendapat bimbingan dan pendampingan teknis.

6. Terdapat batas waktu program.

Pendayagunaan dana zakat untuk kegiatan ekonomi produktif harus disusun berdasarkan batasan siklus waktu produksi tertentu yang direncanakan. Artinya bantuan modal usaha tidak diberikan secara terus menerus kepada mustahik si penerima program, tetapi terbatas sesuai waktu perencanaan usaha. Batasan waktu juga bertujuan untuk menilai tingkat keberhasilan dari program yang dijalankan.

7. Terdapat lembaga penjamin apabila terjadi kegagalan usaha.

Pada dasarnya membangun usaha baru terlebih pada diri seseorang yang belum pernah melakukan kegiatan usaha tetap memiliki risiko gagal. Dan mengingat program penumbuhan usaha baru ini adalah konsepsi dari pendayagunaan dana zakat untuk kegiatan 
Maltuf

ekonomi produktif maka kegagalan usaha sangatlah tidak dibenarkan apabila dibebankan kepada para mustahik penerima program meskipun dalam proporsi atau prosentase yang paling kecil sekalipun. Oleh karena itu agar pendayagunaan dana zakat untuk kegiatan ekonomi produktif bisa berjalan secara kelanjutan maka secara kelembagaan program ini perlu dibentuk sebuah lembaga penjamin.

\section{Beberapa Implementasi Konsepsi Pengunaan Zakat untuk Ekonomi Produktif}

Pendistribusian dana zakat untuk kepentingan kegiatan produktif sudah bukan sebuah wacana lagi karena faktanya sejumlah sejumlah lembaga pengelola zakat di Indonesia sudah mengimplementasikan konsepsi ini. Dinamika atas fenomena ini pun telah menjadi obyek studi atau kajian akademis dari beberapa peneliti, di antaranya adalah:

Pertama, Pengelolaan Dana Zakat Produktif Untuk Pemberdayaan UMKM (Studi Kasus Pada Rumah Zakat di Kota Malang) yang dipaparkan oleh Dzari'atus Sanihah dari Fakultas Ekonomi Universitas Islam Negeri (UIN) Maulana Malik Ibrahim Malang (Sanihah 2015). Kajian tersebut menyimpulkan bahwa: (1) Pola pendayagunaan zakat produktif yang ada di Rumah Zakat di Kota Malang dilakukan dengan memberikan modal usaha kepada mustahik dengan nama program "Senyum Mandiri". Pemilihan nama ini diharapkan para mustahik bisa tersenyum dan mandiri dalam menjalani kehidupannya serta berkecukupan untuk memenuhi kebutuhannya, (2) Skema bantuan yang diterapkan adalah mendistribusikan dana zakat produktif berupa pemberian dana hibah atau dana bantuan murni kepada mustahik yang memiliki usaha (UMKM) dimana mereka tidak berkewajiban mengembalikan dana tersebut, (3) Bentuk bantuan hibah bisa berupa modal usaha atau infrastruktur yang dibutuhkan, (4) Program pemberdayaan ini juga dilengkapi dengan pembinaan, pemberian motivasi usaha, pengawasan dan pelatihan agar penerima program bisa sukses dan merasa bertanggungjawab atas dana yang diterima. 
Kedua, Kajian yang berjudul "Analisis Peranan Dana Zakat Produktif Terhadap Perkembangan Usaha Mikro Mustahik (Penerimaan Zakat) (Studi Kasus Rumah Zakat Kota Semarang) oleh Sintha Dwi Wulansari (Wulansari, Analisis Peranan Dana Zakat Produktif Terhadap Perkembangan Usaha Mikro Mustahik (Penerimaan Zakat) (Studi Kasus Rumah Zakat Kota Semarang) 2013). Kajian ini menjelaskan bahwa, (1) Pendistribusian dana zakat produktif pada Rumah Zakat di Kota Semarang disalurkan pada empat program utama yaitu Senyum Juara (pendidikan), Senyum Mandiri (kesejahteraan ekonomi), Senyum Sehat (kesehatan) dan Senyum Lestari. Tujuan keempat program ini adalah sebagai bentuk ikhtiar Rumah Zakat untuk mengurangi angka kemiskinan dan meningkatkan Indeks Pembangunan Manusia, (2) Skema pemberian zakat produktif berupa bantuan modal kepada mustahik. Proses pemberian zakat produktif terlebih dahulu dilakukan proses analisa oleh pihak Rumah Zakat, (3) Setelah memenuhi semua kriteria pihak Rumah Zakat akan melakukan survei ke lokasi usaha, (4) Setelah ditetapkan mustahik yang berhak menerima bantuan modal maka dilakukan monitoring usaha, agar mustahik dapat dilihat perkembangan usahanya, (5) Indikator keberhasilan dari program Senyum Mandiri salah satunya dilihat dari pendapatan mustahik, apakah ada peningkatan pendapatan setelah jangka satu tahun bantuan diberikan. Indikator lain dilihat dari peningkatan manajerial usaha maupun kelengkapan usaha.

\section{Simpulan}

1. Zakat adalah bentuk ibadah yang diwajibkan bagi setiap umat Islam yang mampu, di mana dalam pelaksanaannya terkandung dimensi sosial ekonomi yaitu berupa praktik redistribusi pendapatan dari mereka yang mampu (muzakki) kepada mereka yang tidak mampu (mustahik). Dengan demikian dalam agama Islam telah berlaku prinsip bagaimana upaya meningkatkan kualitas dan kesejahteraan hidup manusia.

Economica: Jurnal Ekonomi Islam - Volume 8, Nomor 1 (2017) 
Maltuf

2. Sebagai negara muslim terbesar, potensi zakat di Indonesia apabila dikelola dengan baik dan penuh amanah dapat menjadi sumber daya ekonomi untuk usaha-usaha peningkatan kesejahteraan manuasia. Ini artinya zakat merupakan instrumen bagi peningkatan kesejahteraan umat.

3. Konsepsi zakat sebagai instrumen peningkatan kesejahteraan umat dapat diimplementasikan dengan penerapan skema pemberian zakat untuk kegiatan produktif. Penerapan skema ini dapat dibenarkan menurut syariat Islam selama kebutuhan dasar bagi para mustahik sudah terpenuhi.

4. Sejumlah badan atau lembaga pengelola zakat di beberapa kota di Indonesia yang telah menerapkan manajemen secara baik dan modern telah menjalankan skema pendistribusian dana zakat produktif (pemberdayaan ekonomi) berdampingan dengan dana zakat produktif (perlindungan sosial). Sebagian besar tujuan pendayagunaan dana zakat untuk kegiatan ekonomi produktif adalah untuk meningkatkan kemandirian sosial ekonomi para mustahik agar dapat bertransformasi menjadi muzakki.

\section{Daftar Pustaka}

al-Bukhāri, Imam Abi Abdullah Muhammad bin Ismail bin Ibrahim bin Mughirah bin Bardazabah. 1987. Șahịh al-Bukhāri. Beirut: Dār al-Qalam.

al-Ghazzi, Muḥammad Qāsim bin Muhammad. 2005. Fatḥ al-Qarīb fi Sharḥ Alfāz al-Taqrīb. Beirut: Dār Ibn Hazm.

al-Sharbani, Muhammad bin Muhammad al-Khatib. 1321. al-Iqnā' fi Hall Alfaz Abi Shujaj'. Mesir: al-Mațba'at al-Khairiyyat.

Anto, Hendri. 2003. Pengantar Ekonomika Mikro Islam. Yogyakarta: Ekonosia.

Asnaini. 2008. Zakat Produktif dalam Perspektif Hukum Islam. Yogyakarta: Pustaka Pelajar. 
Baehaqi, Ja'far. 2005. "Potensi Zakat sebagai Pilar Perekonomian Umat Pasca Berlakunya UU Nomor 39 Tahun 1999 tentang pengelolaan Zakat (Studi Pengelolaan Zakat di Kabupaten Kendal)." Semarang: Program Magister Ilmu Hukum UNDIP.

Mujieb, M. Abdul. 1994. Kamus Istilah Fiqih. Jakarta: PT Pustaka Firdaus.

Muslim. 1972. Sahịh Muslim. t.tp: Dār Ihyāa al-Turāth al-'Arabi.

Nahaba, Budi. 2012. "Potensi Zakat Bisa Capai Rp 300T Per Tahun." voaindonesia.com.

Nasution, et al. 2008. Indonesia Zakat and Development Report 2009. Depok: CID.

Sanihah, Dzari'atus. 2015. "Pengelolaan Dana Zakat Produktif Untuk Pemberdayaan UMKM (Studi Kasus Pada Rumah Zakat di Kota Malang)." Skripsi, Malang: Fakultas Ekonomi Universitas Islam Negeri (UIN) Maulana Malik Ibrahim Malang.

Sari, Elsi Kartika. 2006. Pengantar Hukum Zakat dan Wakaf. Jakarta: PT Grasindo.

Sariningrum, Siti Zahrah. 2011. "Analisis Faktor-Faktor yang Mempengaruhi Pembayaran Zakat di Kota Palembang." Skripsi, Bogor: Fakultas Ekonomi dan Manajemen IPB.

Shonhaji, Ahmad. 2014. "Mereka Yang Berhak Menerima Zakat." Dompet Dhuafa, April 25.

Suharto, Edi. 2006. Analisis Kebijakan Publik. Bandung: Alfabeta.

Wulansari, Sintha Dwi. 2013. "Analisis Peranan Dana Zakat Produktif Terhadap Perkembangan Usaha Mikro Mustahik (Penerimaan Zakat) (Studi Kasus Rumah Zakat Kota Semarang)." Skripsi, Semarang: Fakultas Ekonomi dan Bisnis, Universitas Diponegoro.

Zuhdi, Masjfuk. 1994. Masail Fiqhiyah (Kapita Selekta Hukum Islam). Jakarta: CV. Haji Masagung.

Zulaikha, Siti. 2012. "Zakat dan Pajak dalam Bingkai Kesejahteraan Sosial." Istinbath: Jurnal Hukum (Sekolah Tinggi Agama Islam Negeri Siwo Metro).

Economica: Jurnal Ekonomi Islam - Volume 8, Nomor 1 (2017)

http://journal.walisongo.ac.id/index.php/economica 